\title{
VARIETAL TOLERANCE OF SUGAR BEET (BETA VULGARIS L.) TO WATER STRESS Lamy M. M. Hamed ${ }^{1} \quad$ ， Eman I.R. Emara ${ }^{2}$
}

\begin{abstract}
Two field experiments were conducted in the experimental farm, faculty of Agriculture, Cairo university, Giza, Egypt during 2014/2015 and 2015/2016 seasons to evaluate the tolerance of two monogerm sugar beet varieties: Puma and Palace cevek, and two multigerm varieties: Monte Bianko and Ninagri to water depletion levels (25, 50 and $75 \%$ of the available soil moisture). Puma variety was the most tolerant sugar beet variety according to stress tolerance index (STI) along with recorded the highest leaf area index (LAI) and plant dry weight at 150, 175 and 200 days after sowing as well as the highest root and sugar yields, followed by Monte Bianko, Ninagri and Palace cevek variety throughout the growing seasons, while the highest sucrose, purity and sugar recovery (SR) percentages resulted from Palace cevek variety. Increasing water depletion level from 25 up to $75 \%$ negatively affect beet growth traits and decreased root yield by 17.45 and $17.44 \%$ and sugar yield by 11.63 and $9.94 \%$ in the first and second seasons, respectively. On the contrary, sucrose, purity and SR significantly increased as water depletion increased, in addition to, the water use efficiency (WUE) increased by 48.3 and $40.1 \%$ in the $1^{\text {st }}$ and $2^{\text {nd }}$ seasons, respectively. Puma variety irrigated with $25 \%$ water depletion produced the highest LAI, plant dry weight, potassium and sodium content as well as root and sugar yields.
\end{abstract}

Keywords: Drought, Tolerance indices, Root yield, Quality, Sugar crops, Water use efficiency

\section{INTRODUCTION}

$\mathrm{D}$ rought is the world's costliest natural disasters, mainly in arid and semi arid regions. About $70 \%$ of the total water consumed in agriculture (Huffaker and Hamilton, 2007). In Egypt, sugar production depends principally on sugar cane and sugar beet crops.

\footnotetext{
${ }^{1}$ Soil and Water Department, Faculty of Agriculture, Cairo University, 12613, Giza, Egypt

${ }^{2}$ Agronomy Department, Faculty of Agriculture, Cairo University, 12613, Giza, Egypt
} 
Sugar cane contribute $41.0 \%$ of total sugar production (2.25 million tons annually), and $59.0 \%$ being for sugar beet (Sugar crops and sugar production in Egypt, Sugar Crops Council Report, 2018).Sugar beet can be grown in a wide range of climate conditions, but drought can be a major cause of yield loss, depending on weather condition, irrigation management, genotype...etc (Kiymaz and Ertek, 2015). Also, Hoffman et al., 2009 and Hassanli et al., 2010 reported that the climatic factors and the irrigation regime have a decisive role in production of sugar beet crop as well as the variety. In this respect, El-Sabbagh et al. (2003) studied the effect of irrigation at 40-45, 60-65 and 80-85\% depletion of field capacity on sugar beet yields. They found that increasing soil moisture depletion from 40-45 to 80-85\% significantly decreased plant growth and root and sugar yields. Bloch et al. (2006) compared three levels of water stress (100, 50 and $20 \%$ of maximum water holding capacity, WHC) on three sugar beet varieties (Cynthia, Dorothea and the hybrid HI0097). They found that leaf and tap root growth and photosynthesis and transpiration rate were distinctly reduced under limited water supply, while sucrose concentration, $\mathrm{Na}, \mathrm{K}$ and amino $\mathrm{N}$ content increased with increasing drought stress. Choluj and Karwowska (2008) and Hussein et al. (2008) used 40, 60 and $80 \%$ depletion of soil water. They noticed a negative relationship between water stress and plant fresh weight, whereas in response to water shortage was the accumulation of sucrose and increase in sugar recovery $\%$ as a result of the reduction in sodium and potassium content as an effect of water deficit. Esmaeili (2011), Gharib and El-Henawy (2011), Topak et al. (2011) and Baigy et al. (2012) reported that increasing water deficit resulted in increasing sugar percentage and improving juice purity due to increasing sodium by increasing nitrogen absorption, whereas root and white sugar yields decrease as water availability decrease. Bahmani et al. (2017) and ElDarder et al. (2017) evaluated the effect of water stress from 60 up to $100 \%$ of crop water requirement. They found that availability of soil water increased root and white sugar yields; however the sugar content was reduced. Mahmoud et al. (2018) investigated the effect of three water stress levels (30, 50 and 70\% of field capacity) on growth, yield and quality of three multigerm and two monogerm sugar beet varieties. They 
found that increasing water stress from 30 up to $70 \%$ of field capacity was significantly decreased beet growth, root yield reduced by 13.6 and $15.6 \%$ and sugar yield obtained by 7.5 and $11.5 \%$, but sucrose, purity and sugar recovery percentages significantly increased. They also reported that monogerm sugar beet varieties were more tolerant to water stress than multigerm varieties according to stress tolerance index (STI). AbouSalama and El-Syiad (2000) and Mekdad (2012) found significant varietal differences of sugar beet crop in leaf and plant weight, sucrose, purity, $\mathrm{K}$ and sugar recovery percentages, while there were no significant differences among varieties concerning root and recoverable sugar yields. Hesadi et al. (2015), Haghverdi et al. (2017) and Mehanna et al. (2017) evaluated different sugar beet genotypes to water stress. They reported that varieties had a significant effect on root and sugar yiels, also they noticed that stress tolerance index (STI) can be used as most suitable indicators for screening of the drought tolerance genotypes. The target of this investigation was to study the effect of water stress levels, varieties and their interaction on growth, yield and quality of multigerm and monogerm sugar beet varieties.

\section{MATERIALS AND METHODS}

\subsection{Experimental site and soil properties}

Two field experiments were carried out in the experimental farm of Faculty of Agriculture, Cairo University, Giza, Egypt during 2014/2015 and 2015/2016 seasons. Chemical and mechanical analyses of the upper $40 \mathrm{~cm}$ of the experimental site in both seasons are presented in Table (1). Average agro-metrological data of the experimental site (Giza) during the growth period in both seasons are presented in Table (2).

\subsection{Studied treatments}

2.2.1. Water regimes: Three water regimes were applied, irrigation at 25, 50 and $75 \%$ depletion of available soil water. By using TDR 300 to measure the available soil water, and quant the amount of water from the following equation: According to Blaney and Criddle, 1962.

$$
Q_{w}=\left[\left(D_{p}\left(Q_{f}-Q_{w}\right) * R_{1}\right) * \text { area per plot }\right]
$$


Where, $\mathrm{Q}_{\mathrm{w}}$ : Amount of requested water per plot ( $\left.\mathrm{m}^{3} / \mathrm{plot}\right), \mathrm{D}_{\mathrm{p}}$ : Level of depletion (i.e. 0.25 or 0.50 or 0.75$), \mathrm{Q}_{\mathrm{f}}$ : Field capacity (41\%), $\mathrm{Q}_{\mathrm{w}}$ : Wilting point $(20 \%)$ and $\mathrm{R}_{1}$ : Root length $(\mathrm{cm})$

2.2.2. Sugar beet varieties: Two monogerm varieties (Puma and Palace cevek) and two multigerm varieties (Monte Bianko and Ninagri), which were obtained from the Sugar Crops Research Institite, Agriculture Research Center, Egypt.

\subsection{Experimental design, sugar beet plantation and some agricultural practice}

A split plot design with four replicates was used; water regimes were arranged in the main plot and sugar beet varieties in the sub plot. The sub plot area was $15 \mathrm{~m}^{2}$ and consisted of five ridges of $5 \mathrm{~m}$ in length and $60 \mathrm{~cm}$ apart and $17.5 \mathrm{~cm}$ between hills. Sowing was on $9^{\text {th }}$ and $8^{\text {th }}$ of October in 2014/2015 and 2015/2016 seasons, respectively. Field was immediately irrigated post planting. Seedlings were thinned at 4-6 leaf stage (40 days from sowing) to ensure one plant per hill. Amount of $70 \mathrm{~kg} \mathrm{P}_{2} \mathrm{O}_{5} \mathrm{ha}^{-1}$ in the form of superphosphate $\left(15.5 \mathrm{P}_{2} \mathrm{O}_{5}\right)$ was applied at sowing. Nitrogen fertilizer at a rate of $240 \mathrm{~kg} \mathrm{ha}^{-1}$ in the form of ammonium nitrate $(33.5 \%$ $\mathrm{N})$ was added in two doses after thinning and four weeks later and potassium fertilizer at a rate of $115 \mathrm{~kg} \mathrm{~K}_{2} \mathrm{O} \mathrm{ha}{ }^{-1}$ in the form of potassium sulphate $\left(48 \% \mathrm{~K}_{2} \mathrm{O}\right)$ was added with the first dose of nitrogen fertilizer. Other cultural practices were carried out as recommended. Harvest of sugar beet plants took place at 200 days from sowing in each season.

\subsection{Studied traits}

\subsubsection{Growth traits}

A random sample of 5 plants were taken at 150, 175 and 200 days after sowing from each plot to determine Leaf area per plant $\left(\mathrm{cm}^{2}\right)$ by using digital area meter model U3100, Leaf area index (LAI) according to Watson, 1958 as well as plant dry weight (g) which drying in an oven at $70^{\circ} \mathrm{C}$ till constant weight.

$$
L A I=\frac{\mathrm{LA}}{\mathrm{P}}
$$

Where LA: leaf area per plant and P: Land area per plant 


\subsubsection{Juice quality traits}

At harvest a sample of 10 plants from each sub plot was taken randomly and the following traits were determined at Delta Sugar Company, Kafr El-Sheikh, Egypt. Total soluble solids (T.S.S) \% was determined by using digital refractometer, model PRI (ATAGO). Potassium and sodium percentages were determined by using Venna, Automation BVAnalyserIIG-16-12-99, 9716JP/ Groningen/ Holland, according to the procedure of Delta Sugar Co., as described by Brown and Lilliland (1964). Sucrose percentage was determined by using Automatic Saccharimeter on aluminum sulphate basis (Carruthers and Oldfield, 1960). Purity and sugar recovery (SR) percentages calculated according to Renfield et al. (1993) as follows:

$$
\text { Purity } \%=(\text { sucrose } \% / \text { T.S.S \% }) * 100)
$$

Sugar recovery $=\{$ Sucrose $\%-0.029-(0.343(\mathrm{Na}+\mathrm{K})-0.094($ amino-N $)\}$

\subsubsection{Yields}

Yields were obtained from the middle three rows of each sub plot. Root yield (ton ha- ${ }^{-1}$ ) and recoverable sugar yield (RSY) (ton ha-1).

$$
\text { RSY }=\text { Root yield (ton/fed) } x \text { Sugar recovery } \%
$$

\subsubsection{Varietal tolerance}

Stress tolerance index (STI) was calculated according to Fernandez (1992):

$$
S T I=\frac{\left(y_{n} \cdot y_{s}\right)}{\left(Y_{n}\right)^{2}}
$$

where $: \mathrm{y}_{\mathrm{s}}$ : genotype yield under water stress, $\mathrm{y}_{\mathrm{n}}$ : genotype yield in normal condition (Without stress) and $Y_{n}$ : mean yieldof genotypes under normal condition.

The genotype with high STI values will be tolerant to drought stress (According to Hesadi et al., 2015).

\subsubsection{Water relations}

\subsubsection{Amount of applied water ( $\mathrm{m} 3$ ha-1)}

Total amount of actual applied irrigation water were 7294.1 and 7795.2 $\mathrm{m}^{3} \mathrm{ha}^{-1}$ for $25 \%$; 5640.0 and $6192 \mathrm{~m}^{3} \mathrm{ha}^{-1}$ for $50 \%$ and 4132.8 and 4636.8 $\mathrm{m}^{3} \mathrm{ha}^{-1}$ for $75 \%$ water depletion in the $1^{\text {st }}$ and $2^{\text {nd }}$ seasons, respectively. 


\subsubsection{Water use efficiency for root yield (WUEry ) (kg m-3)}

WUEry $=\frac{\text { Root yield }\left(\mathrm{kg}^{\left.-\mathrm{ha}^{-1}\right)}\right.}{\text { Amount of water applied }\left(\mathrm{m}^{3} \cdot \mathrm{ha}^{-1}\right)} \cdot \mathrm{kg} \cdot \mathrm{m}^{-3}$, According to Jensen (1983).

\subsection{Statistical analysis}

Data collected were subjected to the proper statistical analysis of variance of split plot design according to the procedures outlined by Snedecor and Cochran (1967). Comparison among treatment means was done using L.S.D. at 5\% level of significance according to Steel and Torrie (1980). All statistical analysis was performed by using analysis of variance technique of (Mstat-C, 1989) Computer software package.

\section{RESULTS AND DISCUSSION}

\subsection{Effect of sugar beet varieties}

Varieties significantly differed in leaf area index (LAI) and plant dry weight at all sampling dates in both seasons (Fig. 1). Puma variety surpassed the other varieties in LAI and plant dry weight followed by Monte Bianko, Ninagri and Palace cevek in a descending order at 150, 175 and 200 days of age in both seasons. In this connection, Ober and Luterbacher (2002) and Rajabi et al. (2009) reported that there were genotypic differences in the sensitivity of leaf expansion to drought as well as dry matter accumulation. The superiority of Puma variety might have been due to its higher dry matter accumulation of leaves and roots as well as leaf chlorophyll content. LAI of all varieties gradually decreased as plants progressive towards maturity. On the other hand, plant dry weight increased towards maturity. The later growth stage,175-200 days of age, of all the studied beet varieties recorded the highest increment in plant dry weight, despite the highest reduction in LAI was recorded. Similar trend in results was reported by Hoffmann (2010) who reported that root dry matter increased up to 27 weeks after sowing, whereas leaf dry weight increased up to 15 weeks, reflecting senescence of leaves as a result of translocation of photosynthates from leaves to roots. Results in Table 3 revealed significant differences among varieties in potassium, sodium, sucrose, purity and sugar recovery percentages in both seasons, 
except sodium and purity percentages in the $1^{\text {st }}$ season. Puma variety recorded the highest potassium \% (1.29 and 1.76\%) and sodium \% (0.68 and $0.72 \%$ ) in the first and second seasons, respectively, followed by Monte Bianko, Ninagri and Palace cevek variety in both seasons. In contrast, Palace cevek variety produced the highest values of sucrose, purity and sugar recovery percentages in both seasons followed by Ninagri, Monte Bianko and Puma in a descending order. The superiority of Palace cevek might have been due to its small size roots and the small roots are assumed to contain higher sucrose content, which reflected positively on purity and sugar recovery values of Palace cevek variety, while vice versa was recorded for Puma variety. Some workers have reported differences among beet varieties in the quality traits (Gobarh and Mekki, 2005; Khalil, 2010; Mekdad, 2012). As reflecting to exhibited varieties differences in the previous traits, root and sugar yields significantly differed (Table 4). The superiority of Puma variety in growth traits, in terms of, LAI and plant dry weight resulted in surpassing the other varieties in beet yields with an average (91.23 and 12.91 ton $\mathrm{ha}^{-1}$ ) over the two growing seasons for root and sugar yields, respectively. The high sugar production of Puma variety as a result of its higher root yield which compensated the lower content of sucrose, purity and sugar recovery percentages and finally sugar yield increased, whereas Palace cevek variety recorded the lowest root and sugar yields in both seasons. These results are in agreement with Zocca (1974), Jassem (1982) and Mohmoud et al. (2018) whom they reported that root and sugar yields of the monogerm varieties were higher than multigerm varieties. Hoffmann et al. (2009) and Haghverdi et al. (2017) found that there were significant differences among sugar beet varieties in root and sugar yields, while Ahmad et al. (2012) found no significant differences in sugar beet yields among varieties. Water use efficiency (WUE) for root yield differed significantly among sugar beet varieties (Table 7) in both seasons. Puma variety recorded the highest values, followed by Monte Bianko, Ninagri and Palace cevek in a descending order in both seasons, reflecting the superiority of Puma variety in root yield. 


\subsection{Effect of water depletion levels}

Leaf area index (LAI) and plant dry weight were significantly affected by water depletion levels at all sampling dates in both seasons, where water depletion markedly decreased both LAI and plant dry weight (Fig. 2). Increasing water depletion level from 25 up to $75 \%$ of the available soil moisture decreased LAI by 20.1, 8.5 and $21.8 \%$ and decreased by 16.4 , 20.8 and $12.1 \%$ as well as plant dry weight decreased by 23.0, 35.3 and $25.4 \%$ and decreased by $24.3,37.2$ and $30.3 \%$ at 150,175 and 200 days after sowing in the $1^{\text {st }}$ and $2^{\text {nd }}$ seasons, respectively. The same trend was reported by Hoffmann (2010) who mentioned that water stress restricted the growth of sugar beet plant organs. Also, Masri et al. (2015) and Haghverdi et al. (2017) found that water deficit hastened the senescence of leaves, which reduced the photosynthetic efficiency of the leaves and the amount of light intercepted by the canopy as reported by Choluj et al. (2004), which were reflected on the reduction in root and leaves dry weight and consequently plant dry weight. Effect of drought treatment at successive growth stages reduced dry matter of the whole plant were also reported by Hussein et al. (2008) and Gharib and El-Henawy (2011). Potassium, sodium, sucrose, purity and sugar recovery percentages significantly affected by water depletion levels in both seasons (Table 5). Potassium and sodium content gradually decreased with increasing water depletion from 25 up to $75 \%$. The decrease amounted to 3.2 and $11.9 \%$ for $\mathrm{K}$ and amounted to 40.0 and $28.8 \%$ for $\mathrm{Na}$ in the $1^{\text {st }}$ and $2^{\text {nd }}$ seasons, respectively. This was in agreement with Choluj et al. (2004), Mahmoodi et al. (2008) and Kiymaz and Ertek (2015). On the contrary, Baigy et al. (2012) found that $\mathrm{K}$ and $\mathrm{Na}$ content were not significantly affected by irrigation treatments. On the other hand, increasing water depletion level from 25 up to $50 \%$ increased sucrose $\%$ by 0.73 and $4.37 \%$, purity $\%$ by 0.48 and $0.40 \%$, and consequently sugar recovery (SR) increased by 1.10 and $2.93 \%$, at the same trend increasing water depletion level from 50 up to $75 \%$ increased sucrose $\%$ by 2.74 and $6.51 \%$, purity $\%$ increased by 3.62 and 1.32 , and SR increased by 5.87 and $5.96 \%$ in the first and second seasons, respectively. This increase in purity and sugar recovery percentages as water depletion increased may be due to the reduction in 
impurities component, potassium and sodium, and to the increase of sucrose percentage. Similar findings were reported by Choluj and Karwowska (2008) whom they noticed that water deficit significantly increased sucrose accumulation and reduced $\mathrm{Na}$ and $\mathrm{K}$. Abdul Malik et al. (2014), Bahmani et al. (2017) and Zare Abyaneh et al. (2017) reported that sugar content and SR were significantly affected by increasing water deficit from 100 to $50 \%$ of irrigation water requirements. On the other hand, Kiymaz and Ertek (2015) reported that SR\% was not significantly affected by irrigation treatments. Results clarified that each increase in water depletion level was accompanied with a significant reduction in root and sugar yields (Table 6). Increasing water depletion level from 25 up to $75 \%$ decreased root yield by 17.49 and $17.44 \%$ and sugar yield decreased by 11.63 and $9.94 \%$ in the first and second seasons, respectively. This reduction in root yield might have been due to the depressive effect of drought stress on beet growth, in terms of, LAI and plant dry weight as mentioned before. It is worth noting that the reduction in root yield accompanying water depletion was not compensated the increase in sucrose, purity and SR\% and by finally sugar yield decreased. The same findings were reported by Yonts et al. (2003), Ucan and Gencoglan (2004), Hosseinpour et al. (2006) and Nourjou (2008) whom they reported that root yield was significantly decreased as irrigation amount decreased, which may be attributed to translocated metabolic products from leaves to root and finally sugar yield decreased. Topak et al. (2016) found that $75 \%$ deficit irrigation decreased sugar yield by 26.97\% compared with full irrigation. Similarly Bahmani et al. (2017) reported that full irrigation produced the highest sugar yield (11.09 ton ha ${ }^{-}$ $\left.{ }^{1}\right)$. Increasing water depletion level from 25 up to $75 \%$ significantly increased water use efficiency (WUE) for root yield by 48.3 and $40.1 \%$ in the $1^{\text {st }}$ and $2^{\text {nd }}$ seasons, respectively (Table 7). These increases were mainly due to that treatment of $75 \%$ water depletion irrigated with the lower quantities of water compared to the other treatments. Similar findings were reported by Topak (2011) and Bahmani et al. (2017) who reported that water stress increased WUE, where irrigate sugar beet crop with $25 \%$ of plant water requirement had the highest WUE for root yield. 


\subsection{Effect of varieties $x$ water depletion levels interaction}

Water depletion levels and varieties interaction exhibited significant effect on growth, quality, yield traits as well as water use efficiency (WUE) in both seasons. The Puma variety irrigated with $25 \%$ soil water depletion produced the highest values of LAI and plant dry weight at all sampling dates in both seasons as well as the highest root yield (97.77 and 95.86 ton ha ${ }^{-1}$ ) and sugar yield ( 12.22 and 12.46 ton ha ${ }^{-1}$ ) in the first and second seasons, respectively. On the other hand, the highest WUE (21.11 and $18.37 \mathrm{~kg} \mathrm{~m}^{-3}$ ) in the $1^{\text {st }}$ and $2^{\text {nd }}$ seasons, respectively, resulted from Puma variety with $75 \%$ water depletion level. The differential yield response of sugar beet varieties to water stress has been reported by Shehata et al. (2000), Ober and Luterbacher (2002) and Moosavi et al. (2017). Also Sadeghian et al. (2000) found that root and sugar yields exhibited large differential genotype responses to drought stress. Some high yielding genotypes were productive in stress and non stress environment. Rajabi et al. (2009) found that all genotypes decreased sugar yield under drought condition in compared to well water condition. On the other hand, the highest sucrose \% (17.48 and $18.76 \%)$, purity \% (88.58 and $85.33 \%)$ and sugar recovery (16.01 and $15.99 \%)$ in the first and second seasons, respectively, resulted from Palace cevek variety grown under $75 \%$ water depletion level. Similar findings were reported by Shehata (2000) and Kiymaz and Ertek (2015) whom they reported that sugar beet varieties responded differently to water deficit with respect to sucrose percentage. Sugar beet varieties differed in their response to drought stress condition according to stress tolerance index (STI) (Table 8). Puma variety was the most tolerant variety, followed by Monte Bianko, Ninagri and Palace cevek variety in a descending order in both seasons. The superiority of Puma variety might be reflected its better LAI, plant dry weight as well as root and sugar yields as previously mentioned. Some workers reported that some genotypes expressed uniform superiority in both stress and non stress condition, meanwhile other genotypes performed favorably only under non stress condition, and sugar beet genotypes differed significantly according to tolerance indices (Sadeghian et al. 2000; Hesadi et al. 2015). 
Table 1. Chemical and mechanical analysis of upper $40 \mathrm{~cm}$ of soil in 2014/2015 and 2015/2016 seasons

\begin{tabular}{ccc}
\hline Analysis & \multicolumn{3}{c}{ Season } \\
\hline & $\mathbf{1}^{\text {st }}$ & $\mathbf{2}^{\text {nd }}$ \\
\hline Chemical analysis & & \\
Available N (\%) & 0.095 & 0.095 \\
Available P (\%) & 0.080 & 0.090 \\
Available K (\%) & 0.660 & 0.680 \\
pH & 8.47 & 8.68 \\
EC (ds/m) & 0.52 & 0.57 \\
Mechanical analysis & & \\
Sand (\%) & 41.5 & 42.5 \\
Silt (\%) & 24.9 & 26.2 \\
Clay (\%) & 33.6 & 31.3 \\
Soil type & & Clay loam \\
\hline
\end{tabular}

Table 2. Average Agro-meteorological data of the experimental site (Giza) during the growth period in both seasons

\begin{tabular}{ccccc}
\hline Month & $\begin{array}{c}\text { T }\left({ }^{\circ} \mathbf{C}\right) \\
\text { Max. }\end{array}$ & $\begin{array}{c}\text { T }\left({ }^{\circ} \mathbf{C}\right) \\
\text { Min. }\end{array}$ & $\begin{array}{c}\text { Aver. } \\
\text { Temp. }\left({ }^{\circ} \mathbf{C}\right)\end{array}$ & $\begin{array}{c}\text { Sum prec. } \\
(\mathbf{m m})\end{array}$ \\
\hline & & \multicolumn{1}{c}{$\mathbf{1}^{\text {st }}$ season 2014/2015 } & \\
Oct-13 & 20.3 & 10.8 & 15.5 & 0.007 \\
Nov-13 & 25.3 & 14.3 & 19.8 & 0.000 \\
Dec-13 & 19.8 & 8.1 & 14.0 & 0.039 \\
Jan-14 & 20.7 & 8.3 & 14.5 & 0.000 \\
Feb-14 & 21.8 & 8.3 & 15.0 & 0.000 \\
Mar-14 & 24.8 & 10.5 & 17.7 & 0.000 \\
Apr-14 & 28.8 & 13.7 & 21.3 & 0.000 \\
May-14 & 32.0 & 17.6 & 24.8 & 0.003 \\
& & $\mathbf{2}^{\text {nd }}$ season 2014/2015 & \\
Oct-14 & 27.2 & 16.4 & 21.8 & 0.000 \\
Nov-14 & 23.7 & 13.0 & 18.3 & 0.003 \\
Dec-14 & 21.6 & 9.8 & 15.7 & 0.000 \\
Jan-15 & 18.9 & 7.5 & 13.2 & 0.001 \\
Feb-15 & 20.4 & 7.3 & 13.8 & 0.000 \\
Mar-15 & 24.4 & 10.0 & 17.2 & 0.000 \\
Apr-15 & 26.8 & 10.9 & 18.8 & 0.000 \\
May-15 & 31.4 & 16.3 & 23.9 & 0.000 \\
\hline
\end{tabular}


Table3. Effect of varieties on juice quality traits over all water depletion levels in both seasons

\begin{tabular}{lcccccccccc}
\hline \multirow{2}{*}{ Varieties } & \multicolumn{3}{c}{ Potassium \% } & \multicolumn{2}{c}{ Sodium \% } & \multicolumn{2}{c}{ Sucrose \% } & \multicolumn{2}{c}{ Purity \% } & \multicolumn{2}{c}{ Sugar recovery \% } \\
\cline { 2 - 11 } & \multicolumn{1}{c}{$\mathbf{1}^{\text {st }}$} & $\mathbf{2}^{\text {nd }}$ & $\mathbf{1}^{\text {st }}$ & $\mathbf{2}^{\text {nd }}$ & $\mathbf{1}^{\text {st }}$ & $\mathbf{2}^{\text {nd }}$ & $\mathbf{1}^{\text {st }}$ & $\mathbf{2}^{\text {nd }}$ & $\mathbf{1}^{\text {st }}$ & $\mathbf{2}^{\text {nd }}$ \\
\hline Puma & $1.29 \mathrm{a}$ & $1.76 \mathrm{a}$ & $0.68 \mathrm{a}$ & $0.72 \mathrm{a}$ & $15.56 \mathrm{~d}$ & $16.94 \mathrm{~d}$ & $84.15 \mathrm{a}$ & $81.75 \mathrm{~d}$ & $13.99 \mathrm{~d}$ & $14.21 \mathrm{~d}$ \\
Palace cevek & $1.20 \mathrm{bcd}$ & $1.56 \mathrm{~d}$ & $0.61 \mathrm{a}$ & $0.66 \mathrm{bcd}$ & $17.29 \mathrm{a}$ & $17.67 \mathrm{a}$ & $86.12 \mathrm{a}$ & $83.30 \mathrm{a}$ & $15.36 \mathrm{a}$ & $14.97 \mathrm{a}$ \\
Monte Bianko & $1.25 \mathrm{ab}$ & $1.67 \mathrm{~b}$ & $0.65 \mathrm{a}$ & $0.68 \mathrm{~b}$ & $16.40 \mathrm{bc}$ & $17.33 \mathrm{bc}$ & $85.23 \mathrm{a}$ & $82.58 \mathrm{bc}$ & $14.72 \mathrm{bc}$ & $14.54 \mathrm{bc}$ \\
Ninagri & $1.24 \mathrm{abc}$ & $1.66 \mathrm{bc}$ & $0.65 \mathrm{a}$ & $0.67 \mathrm{bc}$ & $16.52 \mathrm{~b}$ & $17.39 \mathrm{~b}$ & $85.42 \mathrm{a}$ & $82.69 \mathrm{~b}$ & $14.82 \mathrm{~b}$ & $14.57 \mathrm{~b}$ \\
L.S.D. at 5\% & 0.06 & 0.06 & N.S & 0.03 & 0.31 & 0.19 & N.S & 0.52 & 0.32 & 0.24 \\
\hline
\end{tabular}

Table 4. Effect of varieties of sugar beet yields $\left(\right.$ ton $\left.\mathrm{ha}^{-1}\right)$ over all water depletion levels in both seasons

\begin{tabular}{|c|c|c|c|c|}
\hline \multirow{3}{*}{ Varieties } & \multicolumn{2}{|c|}{ Root yield (ton ha-1) } & \multicolumn{2}{|c|}{ Sugar yield (ton ha ${ }^{-1}$ ) } \\
\hline & \multicolumn{4}{|c|}{ Season } \\
\hline & $\mathbf{1}^{\text {st }}$ & $2^{\text {nd }}$ & $1^{\text {st }}$ & $2^{\text {nd }}$ \\
\hline Puma & $92.76 \mathrm{a}$ & $89.69 \mathrm{a}$ & $12.98 \mathrm{a}$ & $12.84 \mathrm{a}$ \\
\hline Palace cevek & $73.66 \mathrm{~d}$ & $74.09 \mathrm{~d}$ & $11.38 \mathrm{~d}$ & $11.09 \mathrm{~d}$ \\
\hline Monte Biank & $83.14 \mathrm{~b}$ & $81.41 \mathrm{~b}$ & $12.24 \mathrm{bc}$ & $11.84 \mathrm{~b}$ \\
\hline Ninagri & $83.02 b c$ & $80.50 \mathrm{bc}$ & $12.31 \mathrm{~b}$ & $11.74 \mathrm{bc}$ \\
\hline L.S.D. at $5 \%$ & 3.19 & 4.06 & 0.55 & 0.60 \\
\hline
\end{tabular}


Table 5. Juice quality traits of sugar beet as affected by water depletion levels at harvest in both seasons

\begin{tabular}{|c|c|c|c|c|c|c|c|c|c|c|}
\hline \multirow{2}{*}{$\begin{array}{l}\text { Water } \\
\text { Depletion }\end{array}$} & \multicolumn{2}{|c|}{ Potassium \% } & \multicolumn{2}{|c|}{ Sodium \% } & \multicolumn{2}{|c|}{ Sucrose \% } & \multicolumn{2}{|l|}{ Purity \% } & \multicolumn{2}{|c|}{ Sugar recovery \% } \\
\hline & $1^{\text {st }}$ & $2^{\text {nd }}$ & $1^{\text {st }}$ & $2^{\text {nd }}$ & $1^{\text {st }}$ & $2^{\text {nd }}$ & $1^{\text {st }}$ & $2^{\text {nd }}$ & $1^{\text {st }}$ & $2^{\text {nd }}$ \\
\hline 25 & $1.27 \mathrm{a}$ & $1.76 \mathrm{a}$ & $0.75 \mathrm{a}$ & $0.80 \mathrm{a}$ & $16.49 \mathrm{bc}$ & $16.48 \mathrm{c}$ & $83.95 \mathrm{bc}$ & $82.01 \mathrm{bc}$ & $14.34 \mathrm{bc}$ & $14.01 \mathrm{c}$ \\
\hline 50 & $1.24 \mathrm{ab}$ & $1.68 \mathrm{~b}$ & $0.74 \mathrm{ab}$ & $0.68 \mathrm{~b}$ & $16.61 \mathrm{~b}$ & $17.20 \mathrm{~b}$ & $84.35 \mathrm{~b}$ & $82.33 \mathrm{~b}$ & $14.49 \mathrm{~b}$ & $14.42 \mathrm{~b}$ \\
\hline L.S.D. at $5 \%$ & 0.04 & 0.08 & 0.04 & 0.03 & 0.38 & 0.45 & 1.26 & 0.98 & 0.39 & 0.24 \\
\hline
\end{tabular}

Table 6. Sugar beet yields as affected by water depletion in both seasons

\begin{tabular}{|c|c|c|c|c|}
\hline \multirow{3}{*}{ Water Depletion } & \multicolumn{2}{|c|}{ Root yield (ton ha-1) } & \multicolumn{2}{|c|}{ Sugar yield (ton ha-1) } \\
\hline & \multicolumn{4}{|c|}{ Season } \\
\hline & $1^{\text {st }}$ & $2^{\text {nd }}$ & $1^{\text {st }}$ & $2^{\text {nd }}$ \\
\hline 25 & $91.68 \mathrm{a}$ & $89.74 \mathrm{a}$ & $13.15 \mathrm{a}$ & $12.58 \mathrm{a}$ \\
\hline 50 & $82.46 \mathrm{~b}$ & $80.81 \mathrm{~b}$ & $11.95 \mathrm{~b}$ & $11.66 \mathrm{~b}$ \\
\hline 75 & $75.65 \mathrm{c}$ & $74.09 \mathrm{c}$ & $11.62 \mathrm{bc}$ & $11.33 \mathrm{bc}$ \\
\hline L.S.D. at $5 \%$ & 3.91 & 4.97 & 0.67 & 0.72 \\
\hline
\end{tabular}


Table 7. Water use efficiency (WUE) for root yield (kg m-3) as effected by water depletion levels, varieties and their interaction at harvest in 2014/2015and 2015/2016 seasons

\begin{tabular}{|c|c|c|c|}
\hline $\begin{array}{c}\text { Water } \\
\text { depletion } \\
\text { levels }\end{array}$ & Varieties & $\begin{array}{c}\text { First season } \\
2014 / 2015\end{array}$ & $\begin{array}{c}\text { Second season } \\
2015 / 2016\end{array}$ \\
\hline \multirow{4}{*}{$25 \%$} & Puma & 13.40 & 12.30 \\
\hline & Palace cevek & 11.85 & 10.90 \\
\hline & Monte Bianko & 12.29 & 11.41 \\
\hline & Ninagri & 12.14 & 11.14 \\
\hline \multicolumn{2}{|l|}{ Mean } & 12.42 & 11.44 \\
\hline \multirow{4}{*}{$50 \%$} & Puma & 16.34 & 14.39 \\
\hline & Palace cevek & 13.45 & 11.96 \\
\hline & Monte Bianko & 14.48 & 13.12 \\
\hline & Ninagri & 14.26 & 13.03 \\
\hline \multirow[t]{5}{*}{ Mean } & & 14.63 & 13.13 \\
\hline & Puma & 21.11 & 18.37 \\
\hline & Palace cevek & 13.76 & 13.49 \\
\hline & Monte Bianko & 19.38 & 16.14 \\
\hline & Ninagri & 19.42 & 16.09 \\
\hline \multirow[t]{2}{*}{ Mean } & & 18.42 & 16.02 \\
\hline & Puma & 16.95 & 15.02 \\
\hline \multirow{3}{*}{$\begin{array}{c}\text { Mean for } \\
\text { varieties }\end{array}$} & Palace cevek & 13.02 & 12.12 \\
\hline & Monte Bianko & 15.39 & 13.56 \\
\hline & Ninagri & 15.27 & 13.42 \\
\hline \multicolumn{4}{|c|}{ L.S.D. at 5\% for : } \\
\hline \multicolumn{2}{|c|}{ Water depletion (Wd) } & 1.08 & 0.92 \\
\hline \multicolumn{2}{|l|}{ Varieties (V) } & 2.79 & 2.60 \\
\hline \multicolumn{2}{|l|}{$\mathrm{Wd} x \mathrm{~V}$} & 5.47 & 4.87 \\
\hline
\end{tabular}


Table 8. Stress tolerance index (STI) of sugar beet varieties in both seasons

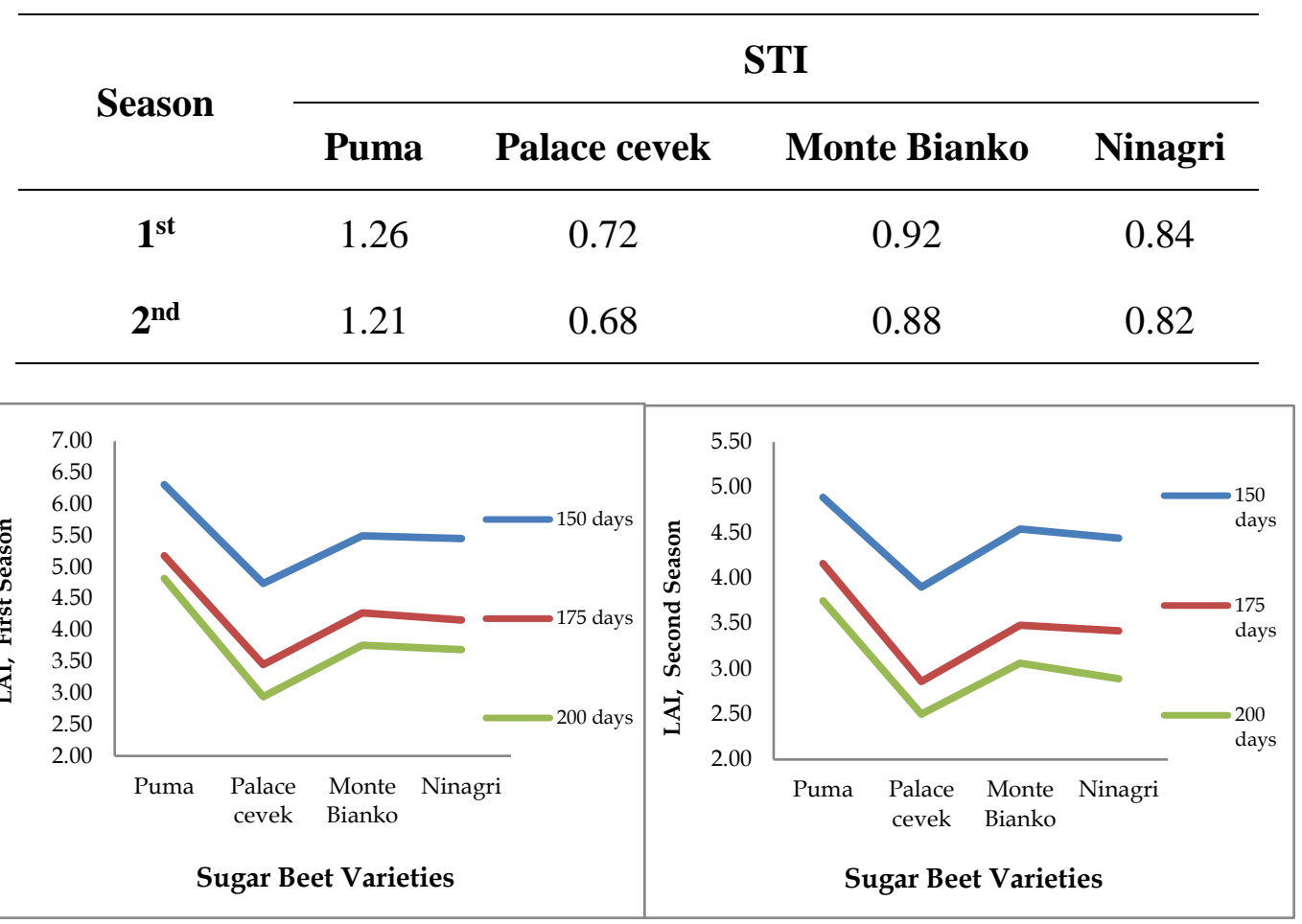

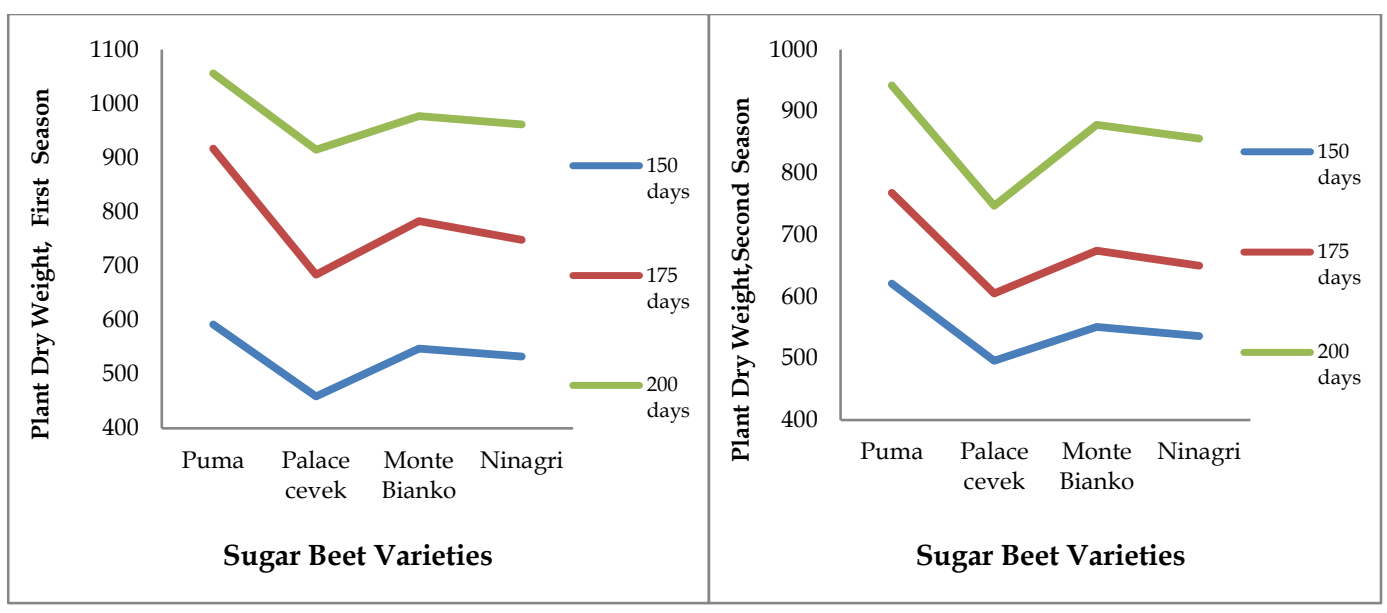

Fig. 1. Leaf area index (LAI) and plant dry weight (g) of some Sugar Beet varieties over all water depletion levels at 150, 175 and 200 days after sowing in both seasons 

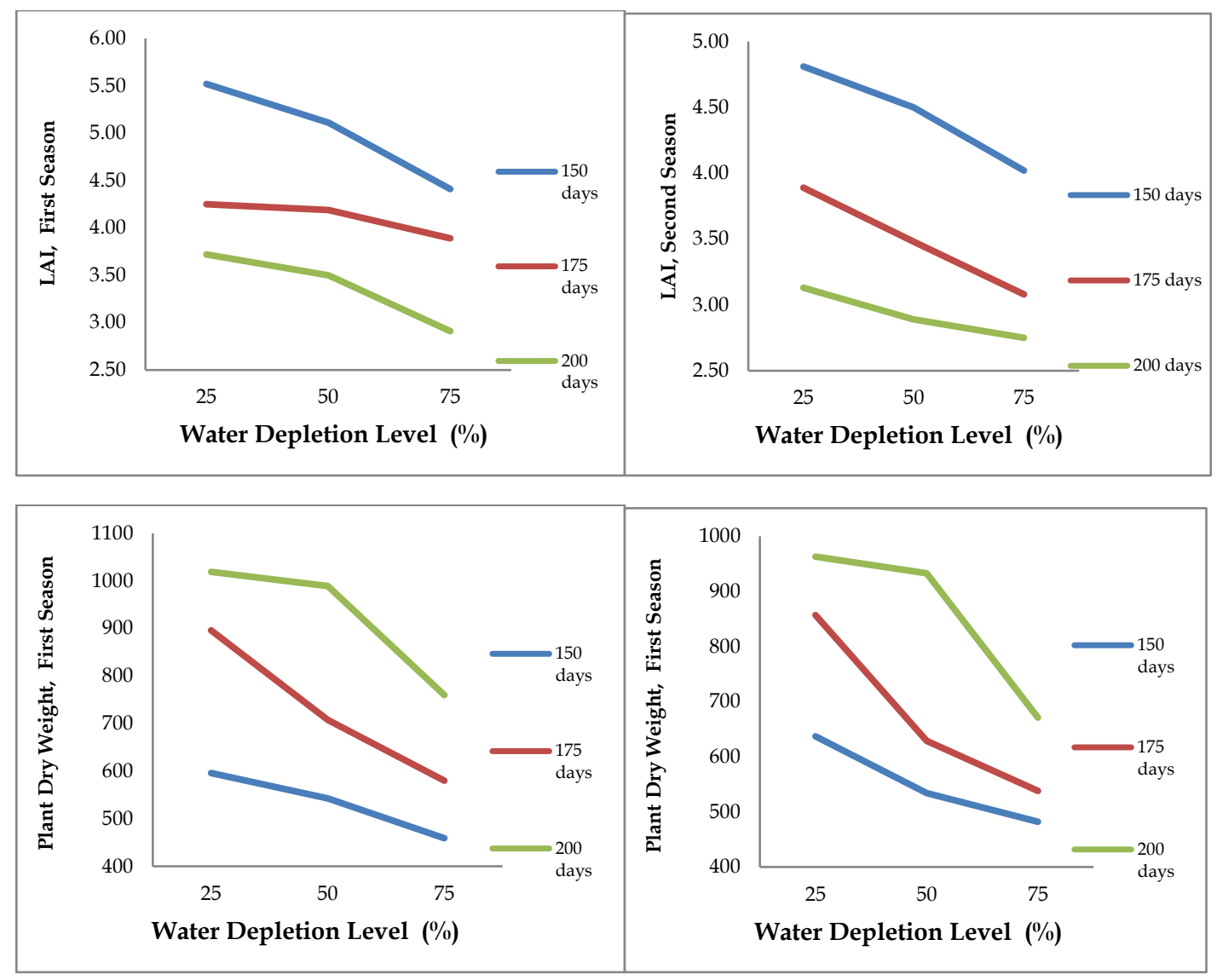

Fig. 2. Leaf area index (LAI) and plant dry weight (g) under water depletion levels at 150,175 and 200 days after sowing in both seasons

\section{CONCLUSION}

Tolerance of four sugar beet varieties to soil water depletion levels was the target of the study. Growth, quality as well as root and sugar yields differed significantly among the studied beet varieties. Puma a monogerm variety recorded the highest growth and yield traits, followed by Monte Bianko, Ninagri and Palace cevek variety. On the other hand, the highest sucrose, purity and sugar recovery \% resulted from Palace cevek variety. $25 \%$ water depletion recorded the best growth and yield traits, whereas the highest water use efficiency resulted from $75 \%$ water depletion treatment. Puma variety irrigated with $25 \%$ water depletion recorded the highest beet yields. Varieties arranged according to stress tolerance index 
(STI) as follows: Puma, Monte Bianko, Ninagri and Palace cevek in a descending order.

\section{REFERENCES}

Abdul Malik, Shakir, A., Khan, M.J., Latif, M. and Zia-ul-Haq. 2014. Yield response and water use efficiency of sugar beet in semi-arid environment under different deficit irrigation regimes, J. Engg. And Appl. Sci., 33(1): 71-80.

Abou-salama, A.M. and El-Syiad, S.I. 2000. Studies on some sugar beet cultivars under middle Egypt conditions. I- Response to planting and harvesting dates. Assiut J. Agric. Sci., 31(1): 137-159.

Ahmad, S., M. Zubair, N. Iqbal, N.M. Cheema and K. Mahmood, 2012. Evaluation of sugar beet hybrid varieties under Thal-Kumbi soil series of Pakistan. Int. J. Agric. Biol., 14: 605-608. 11596/AWB/2012/14-4-605-608

Bahmani, O., Sabziparvar, A.A., Khosravi, R. 2017. Evaluation of yield, quality and crop water stress index of sugar beet under different irrigation regimes. Water Sci. Technol. 17 (2), 571-578. https://doi.org/10.2166/ws.2016.163

Baigy, M.J., Sahebi, F.G., Pourkhiz, I., Asgari, A., Ejlali, F. 2012. Effect of deficit-irrigation management on components and yield of sugar beet. Int. J. Agron. Plant Prod. 3, 781-787.

Blaney, H.F., Criddle, W.D. 1962. Determining Consumptive Use and Irrigation Water Requirements. US Department of Agriculture.

Bloch, D.; Hoffmann, C.M. and Marlander, B. 2006. Solute accumulation as a cause for quality losses in sugar beet submitted to continous and temporary drought stress. J. Agron. Crop Sci., 192: 17-24. doi.org/10.1111/j.1439-037X.2006.00185.X

Brown, J.G., Lilleland, O. 1964. Rapid determination of potassium and sodium in plant materials and soil extracts by flam photometry. J. Am. Soc. Hortic. Sci. 48, 341-346.

Carruthers, A., Oldfield, J.F. 1960. Methods for the assessment of beet quality. Int. Sugar

Choluj, D. and Karwowska, R. 2008. Influence of long-term drought stress on osmolyte accumulation in sugar beet (Beta vulgaris L.) 
plants. Acta. Physiol. Plant, 30: 679-687. DOI: $\underline{10.1007 / s 11738-}$ 008-0166-2

El-Darder, A.M.A.; Gomaa, M.A.; Sayed, M.A. and Kamel, M.Z. 2017. Water stress effects on yield and quality of sugar beet crop in sandy soils. Alex. Sci. Exch. J., 38(4): 828-836.

El-Sabbagh, A.A.; Abd El-Hafez, S.A.; El-Bably, A.Z. and AbouAhmed, E.I. 2003. Sugar beet productivity as affected by soil moisture depletion levels and potassium fertilization. Minufiya $\mathrm{J}$. Agric. Res., 28(2): 527-546.

Esmaeili, M.A. 2011. Evaluation of the effects of water stress and different levels of nitrogen on sugar beet (Beta vulgaris). Int. J. of Biology, 3(2): 89-93. 10.5539/ijb.v3n2p89

Fernandez, G.C. 1992. Effective selection criteria for assessing plant stress tolerance. Proceeding of the International Symposium on Adaptation of Vegetables and Other Food Crops in Temperature and Water Stress 257-270.

Gharib, H.S., El-Henawy, A.S. 2011. Response of sugar beet (Beta vulgaris) to irrigation regime, nitrogen rate and micronutrients application. Alex. Sci. Exchange J. 32 (2), 140-156.

Gobarh, Mirvat, E.M. and Mekki, B.B. 2005. Influence of boron application on yield and juice quality of some sugar beet cultivars grown under saline soil conditions. J. Applied Sci. Res., 1(5): 373379.

Haghverdi, A.; Yonts, C.D.; Reichert, D.L. and Irmak, S. 2017. Impact of irrigation, surface residue cover and plant population on sugar beet growth and yield, irrigation water use efficiency and soil water dynamics. Agric. Water Manage., 180: 1-12. 10.1016/j.agwat.2016.10.018

Hassanli, A.M.; Ahmadirad, S. and Beecham, S. 2010. Evaluation of the influence of irrigation methods and water quality on sugar beet yield and water use efficiency. Agric. Water Manage., 97: 357362. 10.1016/j.agwat.2009.10.010 
Hesadi, P., Taleghani, D.F., Shiranirad, A., Daneshian, J., Jaliliyan, A. 2015. Selection for drought tolerance in sugar beet genotypes (Beta vulgaris L.). InBiol. Forum 7 (1), 1189-1204.

Hoffmann, C.M. 2010. Sucrose accumulation in sugar beet under drought stress. J.

Hoffmann, C.M.; Huijbregts, T.; Swaaj, V.N. and Jensen, R. 2009. Impact of different environments in Europe on yield and quality of sugar beet genotypes. European J. Agron., 30: 17-26. 10.1016/j.eja.2008.06.004

Hosseinpour, M.; Sorooshzadeh, A.; Aghaalikhani, M.; Taleghani, D.F. and Khoramian, M. 2006. The effect of irrigation in spring on water use efficiency and yield of autumn sown sugar beet. J. Sugar Beet, 22(2):35-52.

Huffaker R, Hamilton J. Conflict In: Irrig. Of Agric. Crops. 2007 (Lascano RJ, Sojka RE) $2^{\text {nd }}$ edition, Agronomy Monograph no. 30. ASA-CSSA-SSSA Publishing, p.664.

Hussein, M.M.; Kassab, O.M. and Abo Ellil, A.A. 2008. Evaluating water stress influence on growth and photosynthetic pigments of two sugar beet varieties. Res. J. Agric. Biol. Sci., 4(6): 936-941.

Jassem, M. 1982. Characters and value of sugar beet varieties cultivated in Poland. Gazeta Cukr. 89: 14-16. (C.F.Plant Breeding Abst., 1983, 53(2):1502).

Jensen, M.E. (1983). Design and operation of farm irrigation system. ASAE, Michigan, USA., p.82.

Khalil, Soha, R.A. 2010. Study of performance and behavior of some sugar beet varieties under different environmental conditions. $\mathrm{Ph}$. D. Thesis, Fac. of Agric., Fayoum Univ.

Kiymaz, S. and Ertek, A. 2015. Water use and yield of sugar beet (Beta vulgaris) under drip irrigation at different water regimes. Agric. Water Manage. 158 , 225-234. https://doi.org/10.1016/j.agwat.2015.05.005

Mahmoodi, R., Maralian, H., Aghabarati, A. 2008. Effects of limited irrigation on root yield and quality of sugar beet (Beta vulgaris L.). Afr. J. Biotechnol. 7 (24), 4475-4478. 
Mahmoud, E.A.; Hassanin, M.A.;Borham, T.I. and Emara, Eman, I.R. 2018. Tolerance of some sugar beet varieties to water stress. Agric. Water Manage. 201, 144-151. https://doi.org/10.1016/j.agwat.2018.01.024

Masri, M.I., Ramadan, B.S., El-Shafai, A.M., El-Kady, M.S. 2015. Effect of water stress and fertilization on yield and quality of sugar beet under drip and sprinkler irrigation systems in sandy soil. Int. J. Agric. Sci. 5 (3), 414-425. 10.13140/RG.2.2.17749.27360

Mehanna, H.M.; Safi-naz, S. Zaki and Hussien, M.M. 2017. Influences of irrigation and fertilizer on growth and yield of two sugar beet varieties in Egypt. Middle East J. Agric. Res., 6(4): 1295-1300.

Mekdad, A.A.A. 2012. Response of yield and quality of some sugar beet varieties (Beta vulgaris, L.) to plant density and nitrogen fertilizer under new reclaimed soil conditions. Ph. D. Thesis. Fac. of Agric., Fayoume Univ.

Moosavi, S.G.R., Ramazani, S.H.R., Hemayati, S.S., Gholizade, H. 2017. Effect of drought stress on root yield and some morphophysiological traits in different genotypes of sugar beet (Beta vulgaris L.). J. Crop Sci. Biotech. 20 (3), 167-174. https://doi.org/10.1007/s12892-017-0009-0

Mstat-c, 1989. Users Guide: A Microcomputer Program for the Design, Management and Analysis of Agronomic Research Experiments. Michigan University, East Lansing, MC, USA.

Nourjou, A. 2008. The effect of water deficit on yield and yield components of sugar beet and water productivity. Iranian J. of Irrig. and Drainage, 2(1): 31-42.

Ober, E.S. and Luterbacher, M.C. 2002. Genotypic variation for drought tolerance in Beta vulgaris. Ann. Bot., 89(7): 917-924. Doi: $10.1093 / \mathrm{aob} / \mathrm{mcf093}$

Rajabi, A., Ober, E.S., Griffiths, H. 2009. Genotypic variation for water use efficiency, carbon isotop discrimination, and potential surrogate measure in sugar beet. Field Crops Res. 112 (2), 172 181. 
Renfield, E., Emmerich, A., Baumarten, G., Winner, C., Beiss, U. 1993. Zur voraussage des melosse suckers aus rubenanalyses. Zuker. In: 1st ed. In: Cock, D.A., Scott, R.K. (Eds.), The Sugar Beet Crop 27. Chapman and Hall (World Crop Series), London, UK, pp. 2-15 (1974).

Sadeghian, S.Y.; Fazli, H.; Mohammadian, R.; Taleghani, D.F. and Mesbah, M. 2000. Genetic variation for drought stress in sugarbeet. J. of Sugar Beet Res., 37(3): 55-59.

Shehata, M.M., Azer, S.A., Mostafa, S.N. 2000. The effect of soil moisture stress on some sugar beet varieties. Egypt. J. Agric. Res. 78 (3), 1141-1160.

Snedecor, G.A., Cochran, W.G. 1976. Statistical Methods. Iowa State Univ. Press, Amess.

Steel, R.G., Torrie, H.H. 1980. Principles and Procedures of Statistics, Second ed. Mc Grow Hill, New York.

Sugar Crops and Sugar Production, Sugar Crops Council, 2018. Arabic Ed.

Topak, R., Acar, B., Uyanoz, R., Ceyhan, E. 2016. Performance of partial root-zone drip irrigation for sugar beet production in a semi- arid area. Agric. Water Manage. 176, 180-190. https://dx.doi.org/10.1016/j.agwat.2016.06.004

Topak, R., Suheri, S., Acar, B. 2011. Effect of different drip irrigation regimes in Middle Anatolian, Turkey. Irrig. Sci. 29, 79-89. http://dx.doi.org/10.1007/s00271-010-0219-3

Ucan, K., Gencoglan, C. 2004. The effect of water deficit on yield and yield components of sugar beet. Turkish J. Agric. For. 28, 163172.

Yonts, C.D.; Palm, K.L. and Reichert, D.L. 2003. Late season irrigation management for optimum sugar beet production. J. Sugar Beet Res., 40(1/2):11-28.

Zare Abyaneh, H., Jovzi, M., Albaji, M. 2017. Effect of regulated deficit irrigation, partial root drying and $\mathrm{N}$-fertilizer levels on sugar beet crop (Beta vulgaris L.). Agric. Water Manage. 194, 1323. https://doi.org/10.1016/j.agwat.2017.08.016 
Zocca, A. 1974. The importance of genetically monogerm seed in current beet growing. Experimental research and practical observations. Sementi Elette 20(1-2): 49-61. (C.F. Plant Breeding Abst., 1975, 45(8): 6573

\section{المخلص العربي \\ مقاومة بعض أصناف البنجر للإجهاد المائي

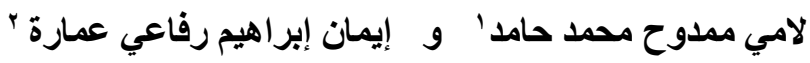

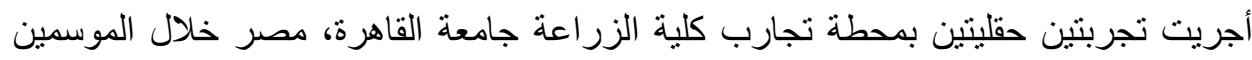

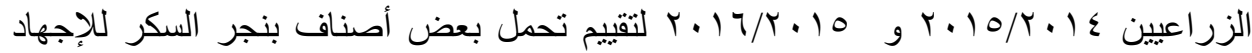

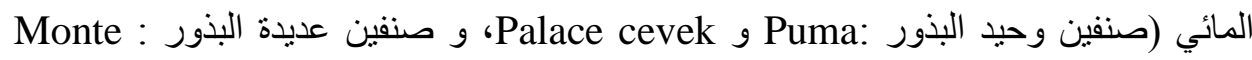
و Bianko في التربة).

أظهرت النتائج تفوق الصنف Puma علي باقي الأصناف طبقا لدليل تحمل الإجهاد (STI) هذا

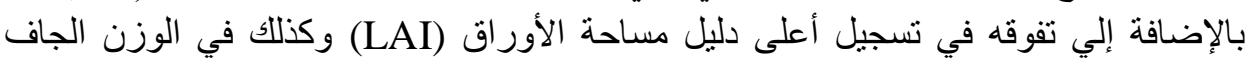

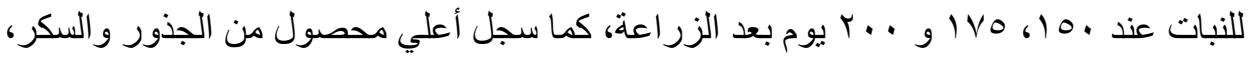

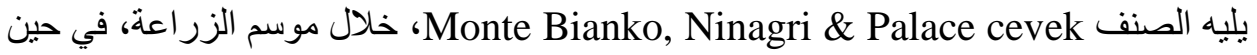
سجل صنف Palace cevek أعلي نسبة سكروز، نقاوة و عائد السكر (SR).

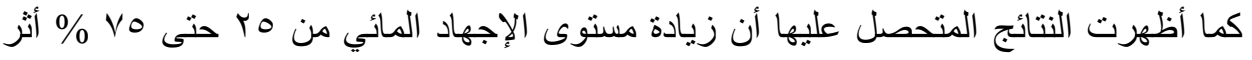

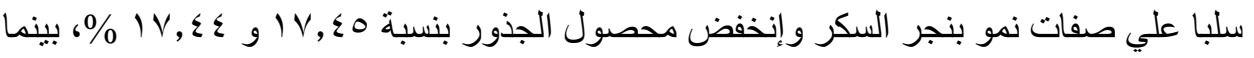

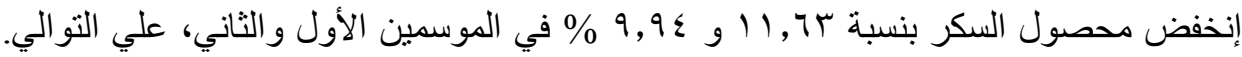

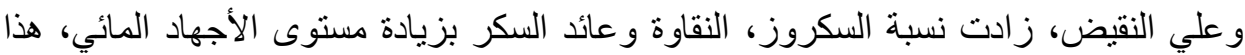

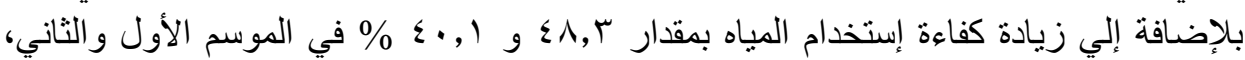

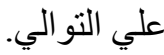

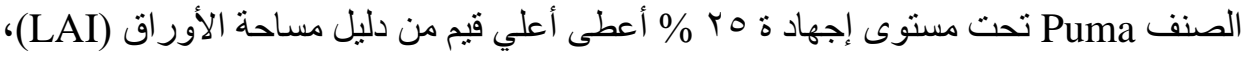
وزن جاف للنبات و محتوى بوتاسيو وصوديوم وكذللك محصول جذور اعلى وسكر. الكلمات الدالة: جفاف، معايير تحمل الجفاف، محصول الجذور، صفات الجودة، محاصيل السكر ، كفاءة إستخدام المياه.

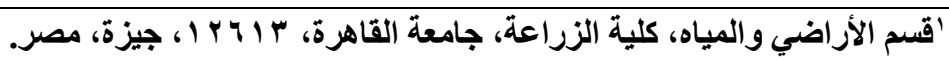

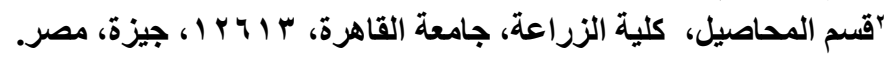

